\title{
DEVELOPMENT OF A MINING SIMULATION MODEL FOR POTASSIUM ORE MINING PLANNING
}

\author{
A.V. Zatonskiy', zxenon@narod.ru, \\ P.A. Yazev², yazev1988@gmail.com \\ ${ }^{1}$ Perm National Research Polytechnic University, Berezniki Branch, Berezniki, \\ Perm region, Russian Federation, \\ ${ }^{2}$ Perm National Research Polytechnic University, Perm, Russian Federation
}

\begin{abstract}
Introduction. In this article, we show the importance of potash fertilizers produced by PJSC Uralkali, Berezniki, Perm Territory for agriculture and the economy in general. A process of potassium ore underground mining is described from breaking up moment till transportation to the surface. An importance of production planning for the mining enterprise functioning is substantiated. Various levels of planning, from a general production plan to a weekly and daily plans are described. The problem of such planning at PJSC Uralkali is in using only integral performance indicators, it leads to significant errors. It is proposed to use simulation modeling as a possible solution to the problem. Purpose of work. The purpose of this work is to develop a simulation model of mining operations, from the process of breaking and transporting ore to a conveyor-transport system, and to test model's applicability for ore mining planning. Since the existing software has a number of limitations in applies to potash mines, a specialized object-oriented library allows modeling queuing systems, multi-agent and active systems is used as a basis for modeling. The limitations and assumptions of the model are described. Materials and methods. The model is igned as a deterministic automaton. The end point for ore mining process modeling is the transfer of ore to the unloading point, because further transportation of ore is not a limiting factor for mining. Conclusion. The special states of all objects of the system including mining combine - self-propelled car - unloading point and all possible transitions between them are described. A data from open sources is taken to check the adequacy of the model. Changes in the simulation results are investigated for various input parameters in the developed software. The simulation results are of a pulsating character due to the periodic execution of the harvester drive away. A productivity of the combine decreases with an increase in the distance traveled by a self-propelled car. The possibility of transition to a stochastic model is investigated. An expected decrease due to an increase in the downtime of the combine is shown. A conclusion about the applicability of the model to improve the quality of planning for underground potassium ore mining is made based on obtained data.
\end{abstract}

Keywords: potash ore, mining machine, modeling, planning, object-oriented library, adequacy research, output pulsation, deterministic model, stochastic model.

\section{Introduction}

Potash fertilizers have great importance for world agriculture, increasing yields storability and resistance of plants to diseases. Three countries, including Russia have more than $80 \%$ of potash ore reserves. Ore reserves and finished products made in Russia take the second place in the world after Canadian products Verkhnekamsk potash ore deposit is developed by PJSC Uralkali (Berezniki town, Perm Region). Uralkali's potassium chloride reserves are more than $20 \%$ of world's reserves.

The most important stage of the production chain is the extraction of ore (halite, sylvinite and carnallite). The ore is mined underground; the depths of the mines are from 200 to 450 meters. The mine rock is both a source of useful materials and a building material to ensure the stability of an ore-breaking floor. The mining is performed in underground blocks by a special underground mining machine. The mining machine loads mined ore into the storage hopper with a capacity of 15 to 25 tons during the operation. The ore is carried from the mining machine to the conveyor-transport system by self-moving cars. The conveyor-transport system aim is the transportation of the ore to shafts. Further the ore is elevated to the surface by skip winder located in the mine shafts.

The long-term plan is usually created for the entire period of deposit exploitation and other plans (annual, monthly and weekly-daily) are based on it [1]. The annual plan is the most important, and a crucial stage of the plan is designed using a block model of the deposit and all known geological 


\section{Управление в технических системах}

information of the blocks. The monthly plan is a more detailed because of geophysical testing using then an annual plan, and a weekly-daily plan is the latest and takes into account schedules of repairs, equipment maintenances and workers jobs [1,2]. Deterministic resource models are typically used to improve the accuracy of mining planes for each mining machine by estimating an ore content in blocks and average values for geological variables, but assumptions of them lead to big errors in planning [3, 4].

A simulation modeling is one of the ways to refine production plans and it has fount application in a wide range of studies. The mining process can be considered as a queuing system (QS) with random distributions of operations times, or as an automaton with the assumption that all planned actions are performed just in time, and emergencies do not arise. The existing mine simulation models focus on coal and nickel mines and cannot be applied for potash mines due to specifical ore composition [5-9]. The paper [10] is devoted to the potash industry but focuses on ore transportation issues. Therefore, it seems relevant to develop a new simulation model for mining operations planning.

\section{Materials and methods}

A simulation model software implementation was created using an object-oriented library developed at the Automation of Technological Processes Department of Berezniki Branch of Perm National Research Polytechnic University. This library allows to simulate complex and multiply connected queuing systems, active, multi-agent systems and deterministic automatons as a particular case of the QS [11]. We consider only a mining operations modeling from the mining machine to an unloading point because a conveyor-transport system has no limitations as an assumption [12].

For a model creation we have to describe all special states of the system "mining machine - selfpropelling car - unloading point" and all possible transitions between them. For example, a "mining machine" object has sixteen states [13]:

1. An ore breaking. The mining machine performs this action from the point where the ore breaking can be started (the beginning of a new stope or partially completed stope continuation) and the storage hopper has an available free space. Ore breaking every time is performed till a user-specified length, and other mining machine could continue it till a new user-specified length.

2. An ore loading from the storage hopper into the self-propelled car is performed when the hopper is full, and the self-propelled car is ready for ore reception and is placed near the mining machine.

3. A mining machine reverse moving is performed after ore breaking ending.

4. A long-term periodic maintenance is carried out after specific time from a previous analogical maintenance, and the mining machine has to be placed at the output of the stope.

5. A passage of the mining machine is transfer from one local place of work to another.

6. A begin of stope mining is driving with a variable cut area from a transportation corridor.

7. An electrical generator transition is performed periodically or according to a user-specified schedule.

8. A downtime of the mining machine for maintenance or change of a staff is performed by a schedule.

9. A transfer of a fan is performed at a certain mining machine distance from a previous fan disposition.

10. A timbering installation is performed at a certain distance from the previous timbering position or at a place of geological deformation (the last one cannot be modeled with assumptions about the deterministic model).

11. A ventilating pipe extending is performed when the mining machine reaches a certain distance from the previous ventilating pipe extending point.

12. An anchor transfer is performed when the mining machine reaches a certain distance from the previous anchor transfer point.

13. A drilling of degasification wells (by short-hole and long-hole methods) is performed when the mining machine reaches a certain distance from the previous point according to a chart of working and type of mining machine.

14. An extension of the power supply wires is performed when the mining machine reaches a maximum distance from electrical generator. Fuel and lubricant storages can be transferred at the same time.

15. A mine surveyor's mark installation or replacement is performed when the mining machine reaches a certain distance from the previous mark.

16. A downtime of mining machine because waiting for the self-propelled car. This unintended idle state occurs when the mining machine reaches such a distance from the unloading point so the car has no time to return before the hopper will full of ore. Mining companies aim is to decrease downtime of the mining machine by changing the stope length and other factors. 
Objects "Self-propelled car" and "unloading point" have six and three states respectively. Fig. 1 is the visual demonstration of all special states and all transitions between them.

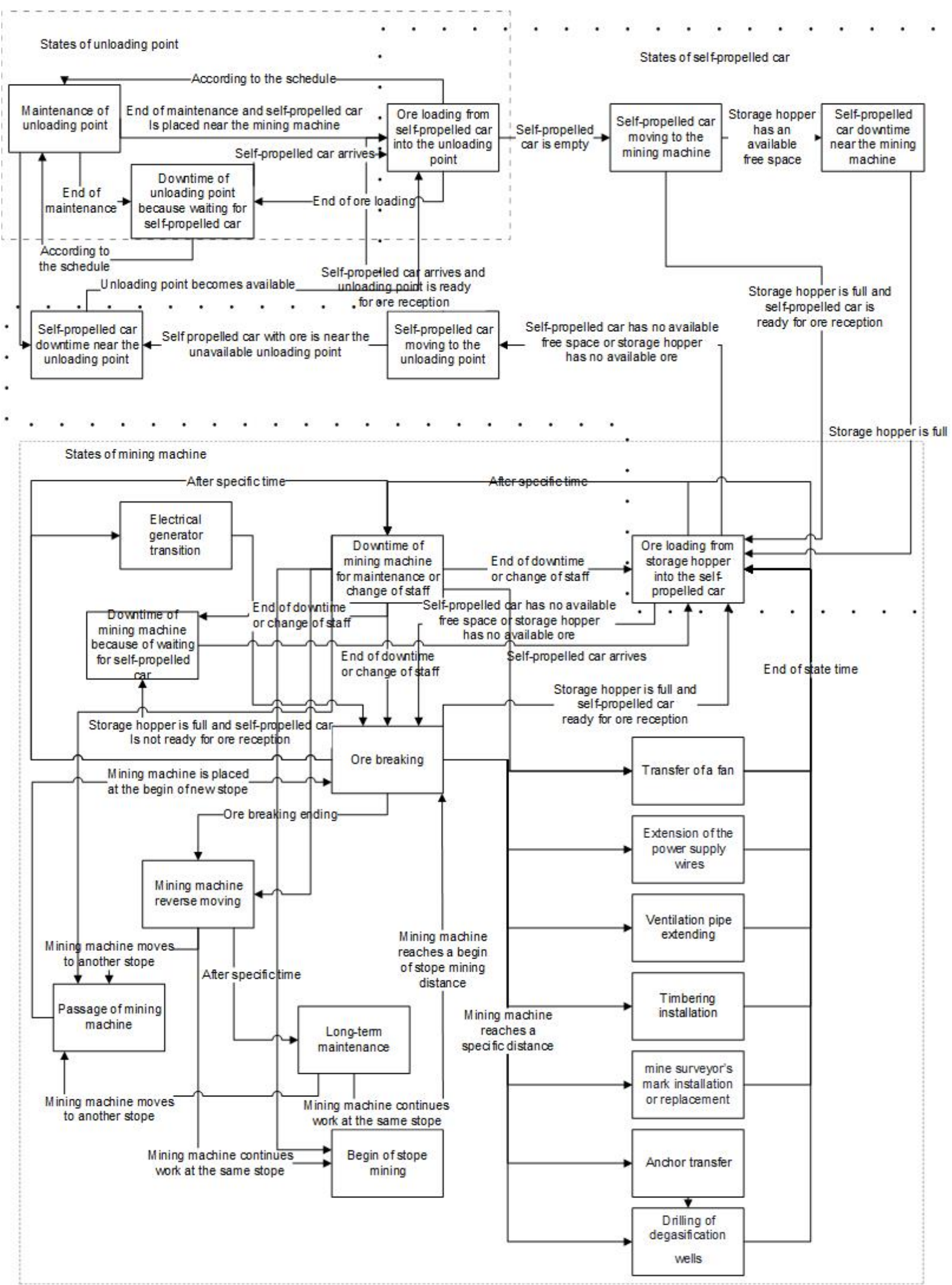

Fig. 1. Scheme of special states and transitions between them 


\section{Управление в технических системах}

\section{Result and discussion}

The model is equipped by the data from open sources about an ore density, a mining machines Ural-20R technical specification, physical parameters in blocks, average times of technological operations and the intervals between them [7]. A validation of the model for adequacy and operability was made by investigating of model responses to changes of parameters. For example, the percentage of ore breaking time should decrease when a distance to unloading point growths because of the mining machine has to wait more time for the self-propelled car return. A first experiment was carried out when the unloading point located at distance of 50 meters from the entrance of the stope. Each unload point served 20 selfpropelled cars from 20 mining machines; the aim of testing is a study of a queue growth. A self-propelled car carriage waiting time is increased for each mining machine as expected (Fig. 2). Salient points on the graph are relevant to mining machine movement between pairs of oppositely located stopes.

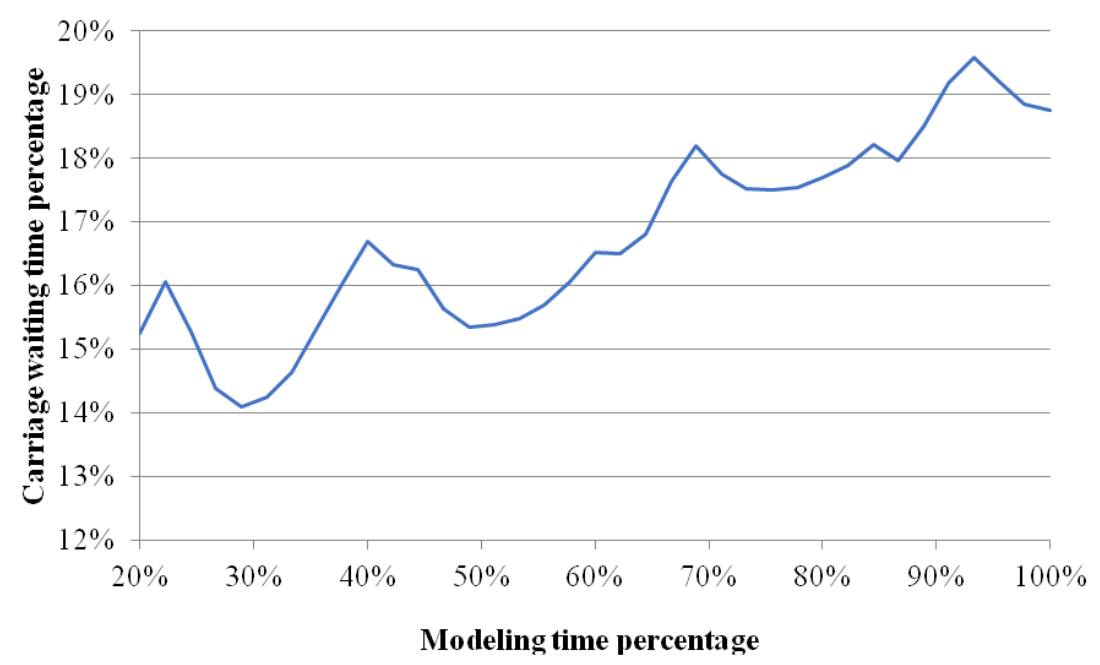

Fig. 2. Dependence between carriage waiting time and modeling time

The graph shows that the productive time of the mining machine is more at the stope begin in a compare with the machine moves farther from the starting point of mining, and self-propelled car distance for carriage grows. Later the production time is stabilized at the same level and further pulsations are explained by the passages of the mining machine and the performing of mandatory operations without carriage waiting.

The influence of the distance from the beginning of the stope to unloading point on the selfpropelled carriage waiting time was studied. It is obviously that waiting time should increase due to passage increase. This assumption is confirmed by experimental results (Fig. 3).

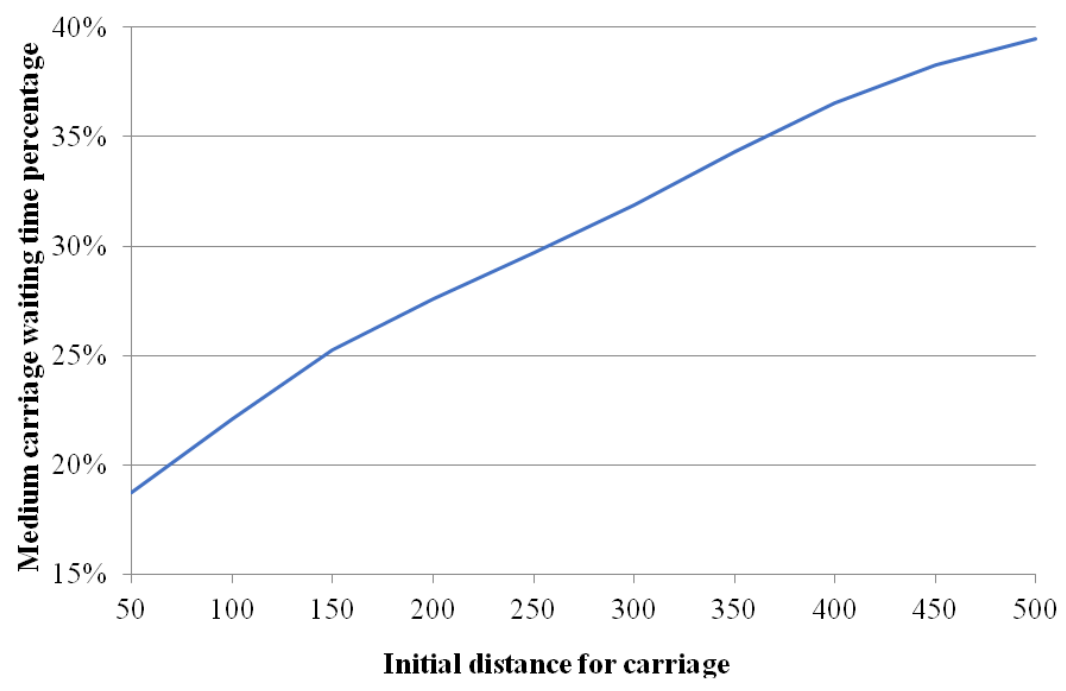

Fig. 3. Dependence between carriage waiting time and distance for carriage 
When the unloading point is moved away from the beginning of the stope, the productive time of the mining machine decreases in accordance with the growing of mandatory operations and idles.

The queuing system performance decreases if stochastic delay appears, especially with a uniform statistical distribution of random numbers $[14,15]$.

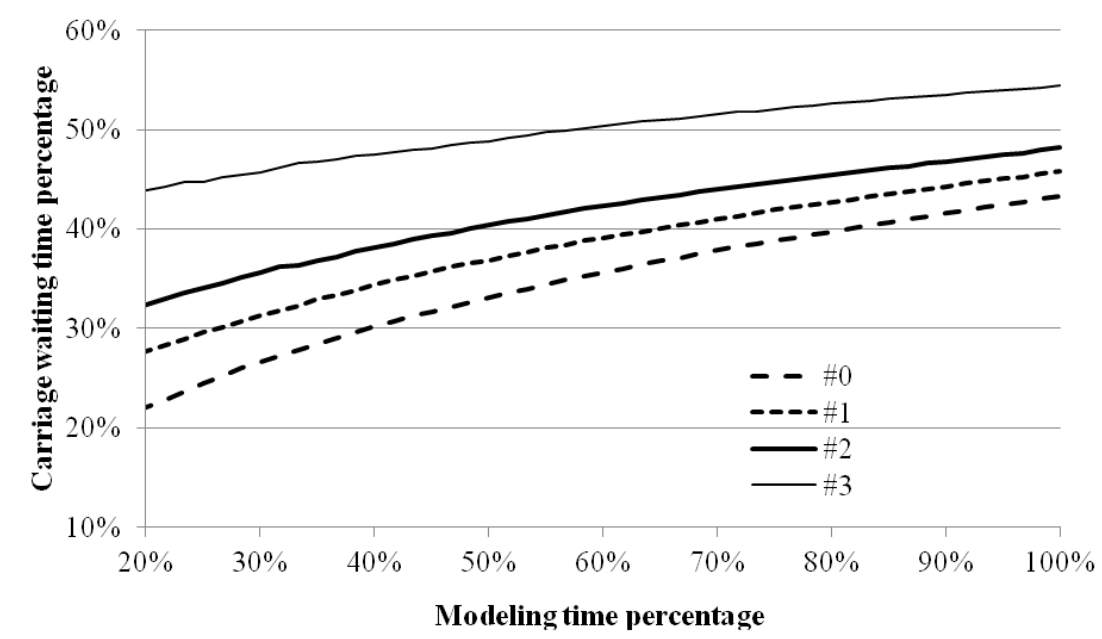

Fig. 4. Growth of carriage waiting time due to stochastic additional delay of carriage: \#0 - no delay, \#1 - delay is $0-1 \mathrm{~min}$, \#2 - delay is 0-3 $\mathrm{min}, \# 3-$ delay is $0-5 \mathrm{~min}$

The following experiment shows that model adequately responses to self-propelled car passage time changes (for example, due to unloading queues, interference with movement, etc.) by growing the carriage waiting time (Fig. 4).

\section{Conclusion}

Thus, the model of underground mining operations is enough adequate and close to reality. It can be used for planning mining operations providing that its parameters values will be refined to the reality.

\section{References}

1. Kaputin Ju.E. Informacionnye tehnologii planirovanija gornyh rabot (dlja gornyh inzhenerov) [Mining planning information technologies (for mining engineers)]. St. Petersburg, Nedra, 2004. 424 p.

2. Hustrulid W., Kuchta M. Open Pit Mine Planning and Design. London, Taylor \& Francis/ Balkema, 1995.

3. Morales N., Seguel S., Cáceres A., Jélvez E., Alarcón M. Incorporation of Geometallurgical Attributes and Geological Uncertainty into Long-Term Open-Pit Mine Planning. Minerals, 2019, no. 9 (2), p. 108.

4. Matamoro M.E.V., Dimitrakopoulos R. Stochastic Short-Term Mine Production Schedule Accounting for Fleet Allocation, Operational Considerations and Blending Restrictions. European Journal of Operational Research, 2016, vol. 255, pp. 911-921.

5. Salama A., Greberg J., Schunnesson H. The Use of Discrete Event Simulation for Underground Haulage Mining Equipment Selection. International Journal of Mining and Mineral Engineering, 2014, vol. 5, no. 3, pp. 256-271.

6. Pop-Andonov G., Mirakovski D., Despotov Z. Simulation Modeling and Analyzing in Underground Haulage Systems with Arena Simulation Software. International Virtual Journal for Science, Technics and Innovations for the IndustryMachines, Technologies, Materials, 2012, no. 6, pp. 48-50.

7. Solov'ev V.A., Sekuncov A.I. Razrabotka kalijnyh mestorozhdenij: Praktikum [Development of potash deposits: Practicum]. Perm, PNRSTU Publ., 2013. 265 p.

8. O'Sullivan D., Newman A. Extraction and backfill scheduling in a complex underground mine. Interfaces, 2014, vol. 44 (2), pp. 204-221.

9. Lukichev S., Nagovitsyn O., Belogorodtsev O. Asystemic Approach to Solving the Mining Technology Tasks Based on Modeling its Objects and Processes. Application of Computers and Ope- 


\title{
Управление в технических системах
}

rations Research in the Mineral Industry Proceedings of the 38th International Symposium, 2017, pp. 29-34.

10. Chudinov G.V. Opyt razrabotki sistemy imitacionnogo modelirovanija gruzopotoka $v$ kalijnyh rudnikah - PK "Rudopotok" [Experience of Developing a System for Simulation of Cargo Traffic in Potash Mines - PC “Ore Flow”]. Imitacionnoe modelirovanie. Teorija i praktika: Sbornik dokladov pjatoj jubilejnoj vserossijskoj nauchno-prakticheskoj konferencii IMMOD-2011. St. Petersburg, CTSS publ., 2011, vol. 2, pp. 311-315. (in Russ.)

11. Zatonskiy A.V., Ufimtseva V.N. [Development of Object Tools for Simulation and Multi-Agent Modeling of Production Processes]. Vestnik Astrahanskogo gosudarstvennogo tehnicheskogo universiteta. Serija: Upravlenie, vychislitel'naja tehnika i informatika, 2018, no. 4, pp. 56-62. (in Russ.)

12. Sobol' A.V., Pinskij V.L. Mehanizacija transportirovanija kalijnyh rud [Mechanization of Transportation of Potash Ores]. Leningrad, Himija Publ., 1973. 160 p.

13. Brusilovskij D.V., Sobol' A.V. Mehanizacija provedenija gornyh vyrabotok na kalijnyh rudnikah [Mechanization of Mine Workings in Potash Mines]. Leningrad, Himija Publ., 1973. 156 p.

14. Zatonskiy A.V., Varlamova S.A., Malysheva A.V., Mjasnikov A.A. [Use of VideoGraphic Information to Refine the Dynamic Stochastic Model of the Potassium ore Flotation Process]. Internetzhurnal "Naukovedenie", 2017, vol. 9, no 2, p. 87. (in Russ.)

15. Zatonskiy A.V. Verification of Kolmogorov Equation Usability for Reproduction and Death Processes. Bulletin of the South Ural State University. Ser. Computer Technologies, Automatic Control, Radio Electronics, 2019, vol. 19, no. 3, pp. 60-67. DOI: 10.14529/ctcr190306

Received 30 September 2020

УДК $622.6+004.92$

DOI: $10.14529 /$ ctcr200405

\section{РАЗРАБОТКА ИМИТАЦИОННОЙ МОДЕЛИ ГОРНО-ВЫЕМОЧНЫХ РАБОТ ДЛЯ ПЛАНИРОВАНИЯ ДОБЫЧИ КАЛИЙНОЙ РУДЫ}

\author{
А.В. Затонский ${ }^{1}$, П.А. Язев ${ }^{2}$ \\ ${ }^{1}$ Пермский национальный исследовательский политехнический университет, \\ Березниковский фрилиал, г. Березники, Пермский край, Россия, \\ ${ }^{2}$ Пермский национальный исследовательский политехнический университет, \\ 2. Пермь, Россия
}

\begin{abstract}
Введение. Показана значимость калийных удобрений, производимых ПАО «Уралкалий», Березники, Пермский край, для сельского хозяйства и экономики в целом. Описан процесс подземной добычи калийной руды от момента его отбойки до транспортировки на поверхность. Показана важность планирования добычи для функционирования горнодобывающего предприятия. Описаны различные уровни планирования от общего плана добычи до недельно-суточного плана. Проблема такого планирования в ПАО «Уралкалий» заключается в использовании только интегральных показателей производительности, что приводит к существенной погрешности. В качестве возможного решения проблемы предлагается использовать имитационное моделирование. Цель работы. Целью данной работы ставится разработка имитационной модели горных работ от процесса отбойки и транспортировки руды до конвейерно-транспортной системы и проверка её применимости для планирования добычи руды. Существующее программное обеспечение имеет ряд ограничений на использование в калийных шахтах, поэтому в качестве основы моделирования использована специализированная объектно-ориентированная библиотека, позволяющая моделировать системы массового обслуживания, многоагентные и активные системы. Описываются ограничения создаваемой модели. Материалы и методы. Модель строится как детерминированный автомат, конечной точкой для моделирования процесса добычи руды является передача руды на точку разгрузки,
\end{abstract}


так как дальнейшая транспортировка руды не является ограничивающим фактором добычи. Заключение. Описаны особые состояния всех объектов системы горный комбайн - самоходный вагон - точка разгрузки и все возможные переходы между ними. Для проверки адекватности модели взяты данные из открытых источников и в разработанном программном обеспечении исследованы изменения результатов моделирования при различных входных параметрах. Результаты моделирования носят пульсирующий характер вследствие периодического выполнения отгонов и перегонов комбайна. При увеличении расстояния, которое проходит самоходный вагон, производительность комбайна снижается. Исследована возможность перехода к стохастической модели, показано ожидаемое снижение ввиду увеличения простоев комбайна. На основе полученных данных делается вывод о применимости созданной модели для улучшения качества планирования подземной добычи калийной руды.

Ключевые слова: калийная руда, горно-выемочная машина, моделирование, планирование, объектно-ориентированная библиотека, исследование адекватности, детерминированная модель, стохастическая модель.

\section{Лuтература}

1. Капутин, Ю.Е. Информаџионные технологии планирования горных работ (для горных инженеров) / Ю.Е. Капутин. - СПб.: Недра, 2004. - 424 c.

2. Hustrulid, W. Open Pit Mine Planning and Design / W. Hustrulid, M. Kuchta. - London: Taylor \& Francis/Balkema, 1995.

3. Incorporation of Geometallurgical Attributes and Geological Uncertainty into Long-Term Open-Pit Mine Planning / N. Morales, S. Seguel, A. Cáceres et al. // Minerals. - 2019. - No. 9 (2). P. 108 .

4. Matamoro, M.E.V. Stochastic short-term mine production schedule accounting for fleet allocation, operational considerations and blending restrictions / M.E.V. Matamoro, R. Dimitrakopoulos // European Journal of Operational Research. - 2016. - Vol. 255. - P. 911-921.

5. Salama, A. The Use of Discrete Event Simulation for Underground Haulage Mining Equipment Selection / A. Salama, J. Greberg, H. Schunnesson // International Journal of Mining and Mineral Engineering. - 2014. - Vol. 5, no. 3. - P. 256-271.

6. Pop-Andonov, G. Simulation Modeling and Analyzing in Underground Haulage Systems with Arena Simulation Software / G. Pop-Andonov, D. Mirakovski, Z. Despotov // International Virtual Journal for Science, Technics and Innovations for the IndustryMachines, Technologies, Materials. - 2012. No. 6. - P. 48-50.

7. Соловьев, В.А. Разработка калийных месторождений: практикум / В.А. Соловьев, А.И. Секуниов. - Пермь: Изд-во ПНИПУ, 2013. - 265 с.

8. O'Sullivan, D. Extraction and backfill scheduling in a complex underground mine / D. O'Sullivan, A. Newman // Interfaces. - 2014. - Vol. 44 (2). - P. 204-221.

9. Lukichev, S. Asystemic Approach to Solving the Mining Technology Tasks Based on Modeling its Objects and Processes / S. Lukichev, O. Nagovitsyn, O. Belogorodtsev // Application of Computers and Operations Research in the Mineral Industry Proceedings of the 38th International Symposium. 2017. - P. 29-34.

10. Чудинов, Г.В. Опыт разработки системы имитационного моделирования грузопотока в калийных рудниках - ПК «Рудопоток» / Г.В. Чудинов // Имитационное моделирование. Теория и практика: сб. докл. пятой юбилейной всерос. науч.-практ. конф. ИММОД-2011. -СПб.: ОАО «ЦТCC», 2011. - T. 2. - C. 311-315.

11. Затонский, А.В. Разработка объектных средств имитаиионного и многоагентного моделирования производственных прочессов / А.В. Затонский, В.Н. Уфимиева // Вестник Астраханского государственного технического университета. Серия: Управление, вычислительная техника и информатика. - 2018. - № 4. - C. 56-62.

12. Соболь, А.В. Механизачия транспортирования калийных руд / А.В. Соболь, В.Л. Пинский. Л.: Химия, 1973. -160 с.

13. Брусиловский, Д.В. Механизачия проведения горных выработок на калийных рудниках / Д.В. Брусиловский, А.В. Соболь. - Л.: Химия, 1973. - 156 с.

14. Использование видеографической информации для уточнения диналической стохастиче- 


\section{Управление в технических системах}

ской модели проиесса флотаџии калийной руды / А.В. Затонский, С.А. Варламова, А.В. Мальщева, А.А. Мясников // Интернет-журнал «Науковедение». - 2017. - Т. 9, № 2. - С. 87.

15. Zatonskiy, A.V. Verification of Kolmogorov Equation Usability for Reproduction and Death Processes / A.V. Zatonskiy // Вестник ЮУрГУ. Серия "Компьютерные технологии, управление, радиоэлектроника». - 2019. - T. 19, № 3. - С. 60-67. DOI: 10.14529/ctcr190306

Затонский Андрей Владимирович, д-р техн. наук, профессор кафедры автоматизации технологических процессов, Пермский национальный исследовательский политехнический университет, Березниковский филиал, г. Березники, Пермский край; zxenon@narod.ru.

Язев Павел Александрович, аспирант, Пермский национальный исследовательский политехнический университет, г. Пермь; уazev1988@gmail.com.

Поступила в редакцию 30 сентября 2020 2.

\section{ОБРАЗЕЦ ЦИТИРОВАНИЯ}

Zatonskiy, A.V. Development of a Mining Simulation Model for Potassium Ore Mining Planning / A.V. Zatonskiy, P.A. Yazev // Вестник ЮУрГУ. Серия «Компьютерные технологии, управление, радиоэлектроника». - 2020. - Т. 20, № 4. - C. 47-54. DOI: $10.14529 /$ ctcr200405

\section{FOR CITATION}

Zatonskiy A.V., Yazev P.A. Development of a Mining Simulation Model for Potassium Ore Mining Planning. Bulletin of the South Ural State University. Ser. Computer Technologies, Automatic Control, Radio Electronics, 2020, vol. 20, no. 4, pp. 47-54. DOI: $10.14529 /$ ctcr 200405 